\title{
High Density Lipoprotein Metabolism in Man
}

\author{
Conrad B. Blum, Robert I. Levy, Shlomo Eisenberg, Marshall Hall, III, \\ Robert H. Goebel, and Mones Berman, Molecular Disease Branch, \\ National Heart, Lung, and Blood Institute, and the Laboratory of Theoretical \\ Biology, National Cancer Institute, National Institutes of Health, \\ Bethesda, Maryland 20014
}

\begin{abstract}
A B S T R A C T The turnover of ${ }^{125}$ I-high density lipoprotein (HDL) was examined in a total of 14 studies in eight normal volunteers in an attempt to determine the metabolic relationship between apolipoproteins A-I (apoA-I) and A-II (apoA-II) of HDL and to define further some of the determinants of HDL metabolism. All subjects were first studied under conditions of an isocaloric balanced diet (40\% fat, $40 \%$ carbohydrate). Four were then studied with an $80 \%$ carbohydrate diet, and two were studied while receiving nicotinic acid ( $1 \mathrm{~g}$ three times daily) and ingesting the same isocaloric balanced diet. The decay of autologous ${ }^{125}$ I-HDL and the appearance of urinary radioactivity were followed for at least $2 \mathrm{wk}$ in each study. ApoA-I and apoA-II were isolated by Sephadex G-200 chromatography from serial plasma samples in each study. The specific activities of these peptides were then measured directly.
\end{abstract}

It was found that the decay of specific activity of apoA-I and apoA-II were parallel to one another in all studies. The mean half-life of the terminal portion of decay was 5.8 days during the studies with a balanced diet.

Mathematical modeling of the decay of plasma radioactivity and appearance of urinary radioactivity was most consistent with a two-compartment model. One compartment is within the plasma and exchanges with a nonplasma component. Catabolism occurs from both of these compartments.

With a balanced isocaloric diet, the mean synthetic rate for HDL protein was $8.51 \mathrm{mg} / \mathrm{kg}$ per day. HDL synthesis was not altered by the high carbohydrate

Dr. Blum's current address is the Department of Medicine, College of Physicians \& Surgeons, Columbia University, New York 10032. Dr. Eisenberg's current address is the Department of Medicine B, Hadassah Hospital, Jerusalem, Israel.

Reprint requests should be addressed to Robert I. Levy, M.D., National Heart, Lung, and Blood Institute, National Institutes of Health, Bethesda, Maryland, 20014.

Received for publication 7 January 1977 and in revised form 6 June 1977. diet and was only slightly decreased by nicotinic acid treatment. These perturbations had effects on HDL catabolic pathways that were reciprocal in many respects. With an $80 \%$ carbohydrate diet, the rate of catabolism from the plasma compartment rose by a mean of $39.1 \%$; with nicotinic acid treatment, it fell by $42.2 \%$. Changes in the rate of catabolism from the second compartment were generally opposite those in the rate of catabolism from the plasma compartment, suggesting that these two catabolic pathways may be reciprocally regulated.

\section{INTRODUCTION}

High density lipoproteins (HDL) ${ }^{1}$ comprise a family of complex particles of phospholipid, cholesterol, and triglyceride noncavalently bound to protein. Its functions are unknown, but available information suggests that HDL may play roles both in triglyceride clearance and in removal of cholesterol from tissues. In connection with the first function, it serves as a reservoir between periods of increased triglyceridemia for apolipoprotein C-II (apoC-II), the activator protein for lipoprotein lipase (1-3). In connection with its other potential role, HDL is the natural substrate for lecithin-cholesterol acyltransferase, the enzyme responsible for esterification of plasma cholesterol in man $(4,5)$. The protein moiety of HDL consists of two major peptides or apolipoproteins, apolipoprotein A-I (apoA-I) and apolipoprotein A-II (apoA-II), and several minor peptides $(6,7)$. ApoA-I and apoA-II have been shown to have clearly different primary and secondary structures as well as immunologic and biochemical characteristics $(8,9)$. ApoA-I, which has a molecular weight of 28,331 , plays a functional role as the activator for lecithin-cholesterol acyltransferase (10). It is rather loosely bound to HDL

\footnotetext{
${ }^{1}$ Abbreviations used in this paper: ApoA-I, II, etc., apolipoprotein A-I, A-II, etc.; HDL, high density lipoprotein; LDL, low density lipoprotein; VLDL, very low density lipoprotein; SDS, sodium dodecyl sulfate.
} 
and can be separated from the rest of HDL by relatively mild procedures (11-14). ApoA-II is associated with HDL lipid more tightly and therefore may play more of a structural role in the HDL particle (15). In man it is present as a dimer with a mol wt of 17,380 (9).

The metabolic relationship between these two peptides has been the subject of some investigation in the past. Studies by Eisenberg et al. (16) have suggested that human apoA-I and apoA-II are catabolized independently when human ${ }^{125}$ I-HDL is injected into the rat.

This report describes kinetic studies of ${ }^{125}$ I-HDL designed to determine whether apoA-I and apoA-II are metabolized independently in man (as are the $\mathrm{B}$ and $\mathrm{C}$ peptides of very low density lipoprotein (VLDL); $(1,2)$. In addition, it describes a series of studies designed to help elucidate the functional role of HDL and to define some of the determinants of its metabolism. The kinetic data are used to develop a mathematical model of HDL apoprotein metabolism. This model helps describe the changes in HDL metabolism induced by two distinct perturbations-an $80 \%$ carbohydrate diet and nicotinic acid treatment. The model's general validity is enhanced by being consistent with normal as well as perturbed conditions of HDL metabolism.

\section{METHODS}

Subjects. The age, weight, plasma cholesterol, triglycerides, and HDL cholesterol of the eight normal volunteer subjects studied are shown in Table I. All were in good health with normal renal, hepatic, and thyroid function. During the initial studies, beginning $2 \mathrm{wk}$ before the main study, all subjects were maintained on a low cholesterol $(<300 \mathrm{mg} /$ day) isocaloric diet with a normal ratio of polyunsaturated to saturated fats $(0.2) .40 \%$ of the calories were provided as fat and $40 \%$ as carbohydrate. In addition, four of the subjects (M. S., D. M., W. G., and S. M.) were also studied after having come to equilibrium for at least $2 \mathrm{wk}$ on an isocaloric diet with $80 \%$ of calories as carbohydrate and $<5 \mathrm{~g}$ fat daily. Subject W. G. had difficulty adhering to this high carbohydrate diet and sustained a $6 \mathrm{~kg}$ weight loss over the $5 \mathrm{wk}$ he received it. Dietary adherence was excellent for the other subjects. Solid food diets with three feedings daily were given in all cases. The $80 \%$ carbohydrate diet contained primarily fruits, fruit juices, and fruit ices, casseroles with waterpacked fat-free tuna or steamed white meat of breast of chicken, egg white, unsalted matzoh, dry cottage cheese, skim milk, and hard candy. Two of the subjects (M. H. and K. J.) were studied on a balanced isocaloric diet before and $3 \mathrm{wk}$ after beginning nicotinic acid treatment $(1 \mathrm{~g}$ three times daily). The eight control studies are designated J. M., K. J., M. S., D. M., W. G., S. M., M. H., and K. J. The four studies with high carbohydrate diet are designated $M$. S.hc, D. $\mathbf{M}_{\cdot \mathrm{hc}}, \mathbf{W}$. G.he and S. M.hc. The two studies with nicotinic acid are designated $M$. $H_{\cdot n}$ and $K$. J.n. Weight varied by $<1 \mathrm{~kg}$ in each study except in W. G.hc. Normal activity was permitted. Supersaturated potassium iodide (1 g/day) was given beginning 3 days before the injection of ${ }^{125}$ I-HDL, and ferrous sulfate, $300 \mathrm{mg}$, was given three times daily. The patients received no other medications. Informed consent was obtained.

Collection of plasma. Blood was obtained in $0.1 \%$ EDTA, usually after an overnight fast (12-14 h), and the plasma was separated at $4^{\circ} \mathrm{C}$ in a refrigerated centrifuge. In three instances during each turnover study, nonfasting blood was obtained; these were at 6,12 , and $36 \mathrm{~h}$ after the 9:00 a.m. initiation of the studies.

Isolation and labeling of HDL. Autologous HDL was isolated at $4^{\circ} \mathrm{C}$ over the density range $1.09-1.21 \mathrm{~g} / \mathrm{ml}$ according to the method of Havel et al. (17). Successive ultracentrifugation was carried out in a Beckman $60 \mathrm{Ti}$ rotor (Beckman Instruments, Inc., Fullerton, Calif.) at $59,000 \mathrm{rpm}$ for $18 \mathrm{~h}$ at $d 1.09 \mathrm{~g} / \mathrm{ml}$, and for $24 \mathrm{~h}$ at $d 1.21$ $\mathrm{g} / \mathrm{ml}$. The HDL thus obtained was resuspended in an $\mathrm{NaCl}-\mathrm{KBr}$ solution of $d 1.21 \mathrm{~g} / \mathrm{ml}$ and washed by ultracentrifugation for $24 \mathrm{~h}$ at $64,000 \mathrm{rpm}$ in a Beckman 65 rotor. $\mathrm{KBr}$ was then removed by at least four successive $30-\mathrm{min}$ dialyses against a 100 -fold excess volume of $0.85 \% \mathrm{NaCl}$ with $0.01 \%$ EDTA (EDTA saline).

The density range $1.09-0.21 \mathrm{~g} / \mathrm{ml}$ was selected to minimize contamination from sinking prebeta lipoprotein should it be present in the plasma of any of the subjects (18) as well as to minimize labeling of $C$ peptides, which may be present primarily in the lowest density range of HDL $(19,20)$. The HDL obtained was free of albumin,

TABLE I

Subjects

\begin{tabular}{|c|c|c|c|c|c|c|c|c|}
\hline Study & Age & Sex & Weight & $\begin{array}{c}\text { Choles- } \\
\text { terol }\end{array}$ & $\begin{array}{l}\text { Triglyc- } \\
\text { eride }\end{array}$ & HDL & VLDL & LDL \\
\hline & & & $k g$ & $\mathrm{mg} / \mathrm{ml}$ & $m g / m l$ & $\mathrm{mg} / \mathrm{ml}$ & $m g / m l$ & $\mathrm{mg} / \mathrm{ml}$ \\
\hline J. M. & 20 & $\mathbf{M}$ & 71 & 1.36 & 0.36 & 0.36 & 0.07 & 0.93 \\
\hline K. R. & 19 & $\mathrm{~F}$ & 54 & 1.92 & 0.72 & 0.40 & 0.14 & 1.38 \\
\hline M. S. & 22 & $\mathrm{~F}$ & 65 & 1.53 & 0.46 & 0.35 & 0.09 & 1.09 \\
\hline M. S. ${ }_{\cdot h c} *$ & & & 65 & 1.46 & 0.72 & 0.20 & 0.14 & 1.12 \\
\hline D. M. & 20 & $\mathrm{~F}$ & 69 & 1.65 & 1.36 & 0.34 & 0.27 & 1.04 \\
\hline D. $\mathrm{M}_{\cdot \mathrm{hc}}{ }^{*}$ & & & 69 & 1.53 & 2.14 & 0.22 & 0.43 & 0.88 \\
\hline W. G. & 23 & $\mathbf{M}$ & 65 & 1.34 & 0.66 & 0.22 & 0.13 & 0.99 \\
\hline $\mathrm{W} . \mathrm{G}_{\cdot \mathrm{hc}}{ }^{*}$ & & & 59 & 1.00 & 0.82 & 0.18 & 0.16 & 0.66 \\
\hline S. M. & 18 & $F$ & 56 & 1.43 & 0.61 & 0.51 & 0.12 & 0.80 \\
\hline S. $M_{\cdot h c}{ }^{*}$ & & & 57 & 1.28 & 0.83 & 0.31 & 0.17 & 0.80 \\
\hline M. H. & 26 & $\mathbf{M}$ & 83 & 1.33 & 0.92 & 0.35 & 0.18 & 0.80 \\
\hline M. $H_{\cdot n} \ddagger$ & & & 83 & 1.21 & 0.84 & 0.42 & 0.17 & 0.62 \\
\hline K. J. & 21 & $\mathbf{F}$ & 60 & 1.53 & 0.71 & 0.37 & 0.14 & 1.02 \\
\hline K. J $\cdot n$ & & & 61 & 1.22 & 0.48 & 0.46 & 0.10 & 0.66 \\
\hline
\end{tabular}

The first of each of the paired studies was conducted with a balanced diet and no drug therapy except for potassium iodide and ferrous sulfate. Weight is expressed in kilograms. Plasma cholesterol and triglycerides are expressed in milligrams per milliliter. VLDL, LDL, and HDL are expressed as milligrams cholesterol per milliliters of plasma.

* Study with $80 \%$ carbohydrate diet.

\$ Study with nicotinic acid treatment ( $3 \mathrm{~g} /$ day). 
low density lipoprotein, and sinking prebeta lipoprotein by immunoelectrophoresis (11).

Labeling with ${ }^{125} \mathrm{I}$ was performed at $\mathrm{pH} 10$ by a modification of the iodine monochloride technique of McFarlane $(21,22)$. Unbound iodine was removed by dialysis in Union Carbide cellulose dialysis tubing (Union Carbide Corp., San Diego, Calif.) for $30 \mathrm{~min}$ against each of at least six successive baths of 500-fold excess volume of EDTA saline. Efficiency of labeling was determined as that portion of ${ }^{125}$ I which, before dialysis, was soluble in $10 \%$ trichloracetic acid and averaged $65 \%$ (range $46-77 \%$ ). In each experiment, $<1 \mathrm{~mol}$ of iodine was bound to each mole of HDL apoprotein, assuming uniform labeling and a mol wt of 30,000 for HDL apoproteins.

Characterization of ${ }^{125} I-H D L$. Lipid labeling was determined as that portion of label which, after dialysis, was found in the nonpolar phase when ${ }^{125} \mathrm{I}-\mathrm{HDL}$ was extracted with chloroform:methanol $(2: 1)$ according to the method of Folch et al. (23). It averaged 1.8\% (range 0.8 $3.2 \%$ ). There was no apparent effect of high carbohydrate diet or of nicotinic acid treatment on the extent of lipid labeling; it averaged 1.9 and $1.8 \%$ in the carbohydrate and nicotinic acid studies, respectively. The lipid phase was dried before counting radioactivity in order to avoid absorption of the gamma emission by chloroform (24). (Absorption was shown to amount to two-thirds of total radioactivity, so a tripling of measured radioactivity accompanied evaporation of the chloroform.) Unbound iodine ( ${ }^{125} \mathrm{I}$ soluble in $10 \%$ trichloracetic acid after dialysis averaged $0.89 \%$ of radioactivity (range $0.2-2.2 \%$ ).

The ${ }^{125} \mathrm{I}-\mathrm{HDL}$ produced a single peak on gamma scanning of its paper electrophoretogram, and this peak was identical in location with the stained band produced by unlabeled HDL from the same subject. Immunoelectrophoresis of ${ }^{125}$ I-HDL against antisera to HDL produced precipitin lines identical to those obtained from coelectrophoresis of unlabeled HDL.

In each study, the ${ }^{125} \mathrm{I}-\mathrm{HDL}$ was incubated for $30 \mathrm{~min}$ at room temperature in $5 \mathrm{ml}$ of autologous fasting plasma at $d 1.063,1.09$, and $1.21 \mathrm{~g} / \mathrm{ml}$ and then ultracentrifuged for $36 \mathrm{~h}$ in a Beckman 40.3 rotor at $4^{\circ} \mathrm{C}$. A mean of $1.2 \%$ (range $0.8-1.4 \%$ ) of total radioactivity was found in the density fraction $<1.063 \mathrm{~g} / \mathrm{ml}$; a mean of $3.2 \%$ (range 2.8 $3.6 \%$ ) of radioactivity was in the density fraction $<1.09$ $\mathrm{g} / \mathrm{ml}$; and a mean of $4.1 \%$ (range $1.7-5.5 \%$ ) of radioactivity was found in the density fraction $>1.21 \mathrm{~g} / \mathrm{ml}$. Recovery in these ultracentrifugations averaged $100 \%$ (SD 5), after correction for absorption of radiation by $\mathrm{KBr}(24)$.

In five of the studies (S. M.ne, K. J., K. J.n, M. H., M. H.n ), the distribution of ${ }^{125} \mathrm{I}$ among the peptides of HDL was determined by counting radioactivity in the sliced segments of polyacrylamide gels after subjecting the ${ }^{125} \mathrm{I}$ apoHIDL and unlabeled carrier apoHDL to sodium dodecyl sulfate (SIS) polyacrylamide gel electrophoresis by a modification of the method of Weber and Osborn (25). A mean of $45.3 \%$ (SD 2.9) of radioactivity migrated with apoA-I; a mean of $38.6 \%$ (SD 1.6) migrated with apoA-II; and a mean of $1.9 \%$ (SD 1.4 ) migrated with the $\mathrm{C}$ peptides. A mean of $9.7 \%$ (SD 1.7) of radioactivity was found in the upper portion of the gels, representing higher molecular weight constituents or aggregates of apoA-I or apoA-II. Furthermore, $0.7 \%$ (SD 0.3 ) was found in the unstained zone between apoA-II and the $C$ peptides. Nicotinic acid treatment produced no consistent change in the pattern of distribution of radioactivity among peptides.

The turnover studies. ${ }^{125} \mathrm{I}-\mathrm{HDL}$ was sterilized by passage through a Millipore filter $(0.45-\mu \mathrm{m}$ pore size, Millipore Corp., Bedford, Mass.) and tested for the presence of bac- teria and pyrogens as previously described (22). Within 5 days of obtaining the subjects' plasma, $25 \mu \mathrm{Ci}$ of autologous ${ }^{125}$ I-HDL (50 $\mu \mathrm{Ci}$ for subjects $\mathrm{K}$. R. and J. M.) were reinjected intravenously. Blood samples were then obtained at $6,12,24$, and $36 \mathrm{~h}$, and then daily for $2 \mathrm{wk}$ after injection ( $3 \mathrm{wk}$ for both studies of S. M. and $4 \mathrm{wk}$ for K. J. and J. M.). Decay of radioactivity in 2-ml samples of plasma was measured. Complete urine collections were performed during each study, the termination of collection periods being the times when blood samples were obtained. Urinary radioactivity for each collection was measured. 24-h fecal excretion of radioactivity was measured on the 6 th day after injection in subjects $\mathrm{K}$. J. and $\mathbf{M}$. $\mathrm{H}$. during nicotinic acid treatment. It amounted to $<0.05 \%$ of urinary excretion for that time period.

The decay over time of specific radioactivity of apoA-I and apoA-II was measured directly in each study. On selected days in each study $120 \mathrm{ml}$ samples of blood were obtained by plasmapheresis. This was done at the following times in all studies but K. R. and J. M.: $10 \mathrm{~min}$ after injection and $1,4,7,10,12$, and 14 days after injection. In the studies of S. M. it was also done 18 and 21 days after injection. In K. R. these large samples were obtained 10 min and 1,5 , and 9 days after injection. In J. M. they were obtained at $10 \mathrm{~min}$ and $1,5,9,13$, and 19 days after injection.

HDL in each large sample was isolated by two successive ultracentrifugations at salt $d 1.063$ and $1.21 \mathrm{~g} / \mathrm{ml}$ at $59,000 \mathrm{rpm}$ in a Beckman $60 \mathrm{Ti}$ rotor. It was then dialyzed twice against a 100 -fold excess volume of $0.01 \%$ $\mathrm{NH}_{4} \mathrm{HCO}_{3}$ with $0.01 \%$ EDTA at $\mathrm{pH} 8.2$, lyophilized, and delipidated with chloroform:methanol $(2: 1)$.

The apoHDL was dissolved in $0.01 \% \mathrm{NH}_{4} \mathrm{HCO}_{3}$ with $0.01 \%$ EDTA and $3 \mathrm{M}$ guanidine $\mathrm{HCl}$ at $\mathrm{pH} 8.2$. It was then fractionated over a glass column packed with Sephadex G-200 (superfine) and $4 \mathrm{~mm}$ glass beads. Fractions near the peaks gave apoA-I and apoA-II purity as shown by SDS gel electrophoresis (Fig. 1). Measurements of protein and radioactivity from these pure fractions yielded the specific activity decay curves.

Analytical techniques. Protein was measured by the method of Lowry et al. (26). Lipid phosphorus was measured by the method of Bartlett (27). Cholesterol in HDL was measured by the method of Chiamori and Henry (28). For this purpose, HDL was isolated by two different techniques: by precipitation of VLDL and low density lipoprotein (LDL) with heparin-manganese (29; Table I), and by two successive ultracentrifugations of plasma at salt $d$ 1.09 and $1.21 \mathrm{~g} / \mathrm{ml}$ (Table II). Total plasma cholesterol and triglycerides were determined by AutoAnalyzer II methodology (30, 31). VLDL cholesterol was estimated as one-fifth the plasma triglycerides (32). LDL cholesterol was determined as the difference between total plasma cholesterol and the sum of VLDL and HDL cholesterol.

SDS-polyacrylamide gel electrophoresis of the apoproteins of HDL was performed by a modification of the method of Weber and Osborn (25). $13 \%$ gels were prepared with $0.5 \%$ diallyltartardiamide (33) as the cross-linker and $0.05 \mathrm{M}$ Tris buffer at $\mathrm{pH} 8.2$. They were run at $8 \mathrm{~mA} /$ tube at room temperature and stained with $0.1 \%$ Coomassie Blue in $5 \%$ acetic acid and $50 \%$ methanol. Destaining was performed by diffusion into $7.5 \%$ acetic acid with $5 \%$ methanol. ApoA-I and apoA-II isolated by Sephadex G-200 chromatography produced distinct bands in this system. When known activities of ${ }^{125} \mathrm{I}$-apoA-I and ${ }^{125} \mathrm{I}$-apoA-II were coelectrophoresed, complete recovery of radioactivity was found in the corresponding bands in the gels.

Radioactivity was counted with a Packard model no. 


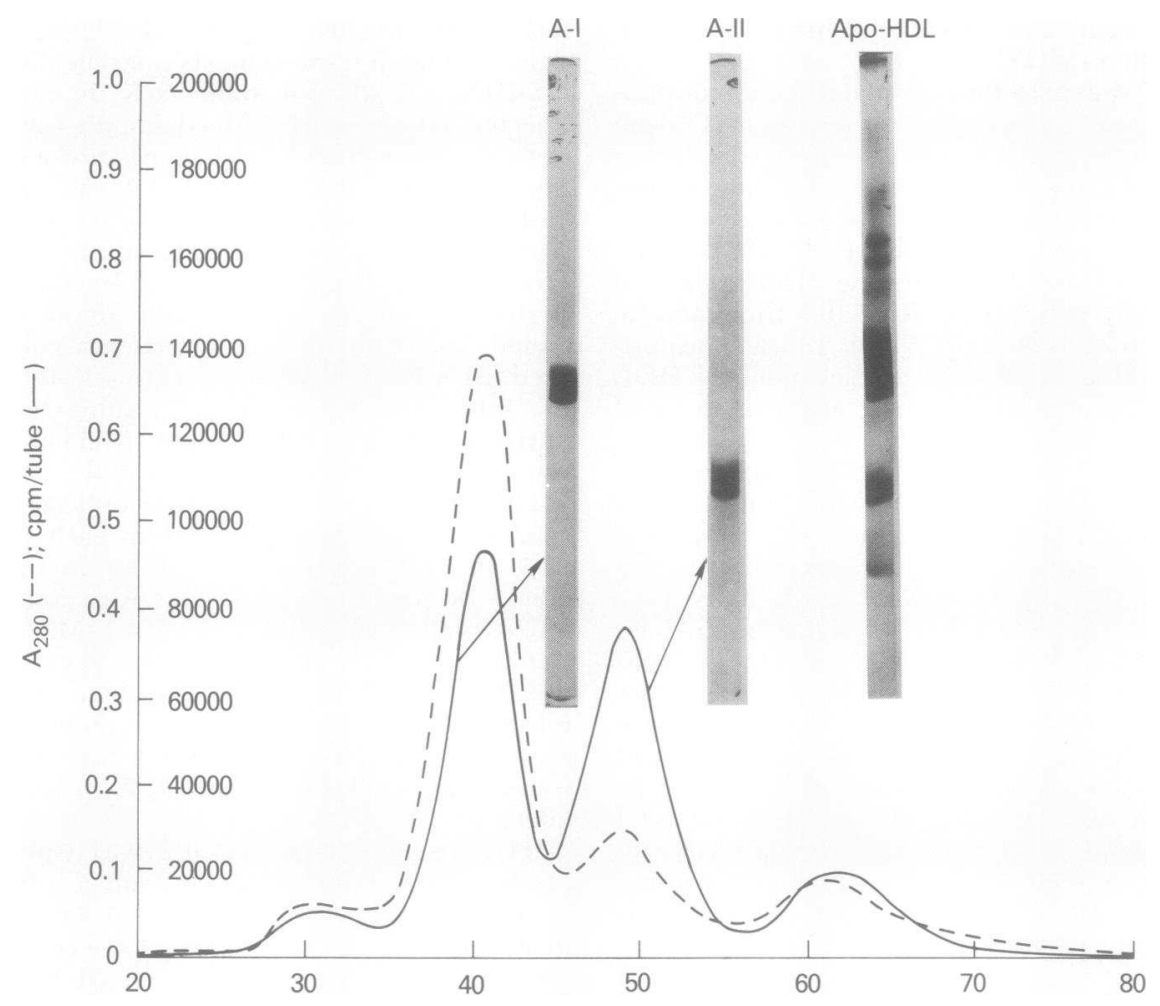

FIGURE 1 Profiles of radioactivity and optical density elution from Sephadex G-200 (superfine) column used for specific activity determination for apoA-I (A-I) and apoA-II (A-II). Samples for measurement of specific activity were taken from tubes 39 and 51 . The $2.0 \times 200-\mathrm{cm}$ glass column packed with Sephadex G-200 (superfine) and $4 \mathrm{~mm}$ glass beads was eluted with $0.05 \mathrm{M}$ Tris, pH 8.2 , with $6 \mathrm{M}$ urea by a pressure of $30 \mathrm{~cm}$ of the buffer. 10-15 $\mathrm{mg}$ of apoHDL was applied to

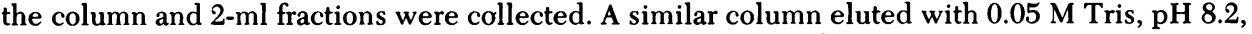
and $4 \mathrm{M}$ guanidine $\mathrm{HCl}$ was also used and gave identical results.

3375 gamma counter (Packard Instrument Co., Inc., Downers Grove, Ill.). Efficiency of counting was 55\%. Correction for absorption by $\mathrm{KBr}$ was made when appropriate (24).

Compositional studies. HDL was isolated quantitatively from $5 \mathrm{ml}$ of plasma in the density range $1.09-1.21 \mathrm{~g} / \mathrm{ml}$ for compositional studies. This density range was selected because it corresponded to the density of the injected ${ }^{125} \mathrm{I}-\mathrm{HDL}$. The isolation was performed at $4^{\circ} \mathrm{C}$ with two ultracentrifugations only, $24 \mathrm{~h}$ at $1.09 \mathrm{~g} / \mathrm{ml}$ and $48 \mathrm{~h}$ at $1.21 \mathrm{~g} / \mathrm{ml}$ at $39,000 \mathrm{rpm}$ in a Beckman 40.3 rotor. The product was not washed with an additional ultracentrifugation at $1.21 \mathrm{~g} / \mathrm{ml}$ in order to minimize preferential loss of apoA-I $(11,13,15)$. Protein concentration was measured. A portion of the isolated HDL was then extracted with chloroform;methanol $(2: 1)$ according to the procedure of Folch et al. (23). Cholesterol in this extract was measured in all studies (28).

The relative masses of apoA-I and apoA-II were determined in the HDL isolated for labeling for each study except J. M. and K. R. The HDL was lyophilized and then delipidated with chloroform:methanol $(2: 1)$. The apoproteins were dissolved in $0.01 \% \mathrm{NH}_{4} \mathrm{HCO}_{3}$ at $\mathrm{pH} 8.2$ with $3 \mathrm{M}$ guanidine $\mathrm{HCl}$. They were then fractionated over a $1.2 \times 150-\mathrm{cm}$ glass column packed with Sephadex G-200 (superfine). The column was equilibrated and eluted with $0.05 \mathrm{M}$ Tris at $\mathrm{pH} 8.2$ with $6 \mathrm{M}$ urea. Column recoveries of radioactivity averaged $100.2 \%$ (SD 5). The elution profiles were of very high resolution and permitted complete collection of apoA-I and apoA-II in separate pools. These pools were dialyzed against $0.01 \% \mathrm{NH}_{4} \mathrm{HCO}_{3}$ at $\mathrm{pH} 8.2$ and concentrated by lyophilization. Correction for loss in dialysis was made according to recovery of radioactivity. Two samples of apoHDL $\mathrm{H}_{2}$ isolated from the plasma of normal volunteers (over the density range 1.063-1.125 $\mathrm{g} / \mathrm{ml}$ ) were subjected to duplicate column runs and analysis to test the precision of these determinations of apoHDL composition. The results are presented in Table III, with subject identification codes TP and DD.

\section{RESULTS}

Compositional studies. The composition of HDL $(d=1.09-1.21 \mathrm{~g} / \mathrm{ml})$ isolated from each subject during each study is given in Table II. It can be seen that in these normal subjects on a balanced diet HDL protein levels varied over more than a twofold range from 0.62 to $1.39 \mathrm{~g} / \mathrm{ml}$ of plasma. However, the composition of HDL did not vary greatly among subjects, the mean ratio of cholesterol: protein being 0.34 (SD 0.033) and that of cholesterol: phospholipid being 0.65 (SD 0.097).

With carbohydrate feeding, HDL protein, choles- 
TABLE II

HDL Composition*

\begin{tabular}{|c|c|c|c|c|c|c|}
\hline Study & Protein & $\begin{array}{l}\text { Phospho- } \\
\text { lipid }\end{array}$ & $\begin{array}{l}\text { Choles- } \\
\text { terol }\end{array}$ & $\begin{array}{c}\text { Triglyc- } \\
\text { eride }\end{array}$ & $\begin{array}{l}\text { Choles- } \\
\text { terol/ } \\
\text { Protein }\end{array}$ & $\begin{array}{c}\text { Choles- } \\
\text { terol/ } \\
\text { Phospho- } \\
\text { lipid }\end{array}$ \\
\hline J. M. & 0.93 & ND $\ddagger$ & ND $\$$ & NDt & ND $\ddagger$ & NDt \\
\hline K. R. & 1.02 & NDt & ND & NDt & ND $\ddagger$ & ND $\ddagger$ \\
\hline M. S. & 0.62 & 0.34 & 0.24 & 0.028 & 0.39 & 0.71 \\
\hline M. S. ${ }_{\text {hc }} \S$ & 0.50 & 0.25 & 0.16 & 0.028 & 0.32 & 0.64 \\
\hline D. M. & 0.95 & 0.43 & 0.32 & 0.064 & 0.34 & 0.74 \\
\hline D. $\mathbf{M}_{\cdot h \mathrm{hc}} \S$ & 0.72 & 0.33 & 0.20 & 0.062 & 0.28 & 0.61 \\
\hline W. G. & 0.62 & 0.26 & 0.20 & ND & 0.32 & 0.77 \\
\hline W. G.hc $\$$ & 0.54 & 0.31 & 0.17 & ND & 0.31 & 0.55 \\
\hline S. M. & 1.39 & 0.80 & 0.48 & 0.068 & 0.35 & 0.60 \\
\hline S. $M_{\cdot h c} \S$ & 1.11 & 0.63 & 0.29 & 0.088 & 0.26 & 0.46 \\
\hline M. H. & 1.08 & 0.55 & 0.31 & 0.088 & 0.29 & 0.56 \\
\hline M. H.n" & 1.11 & 0.60 & 0.37 & 0.064 & 0.33 & 0.62 \\
\hline K. J. & 1.08 & 0.69 & 0.37 & 0.086 & 0.34 & 0.51 \\
\hline $\mathrm{K} \cdot \mathrm{J} \cdot \mathrm{n}$ & 1.07 & 0.73 & 0.44 & 0.060 & 0.41 & 0.60 \\
\hline$P \mathbb{9}$ & $<0.0$ & $<0.5$ & $<0.02$ & $<0.5$ & $<0.0$ & NS \\
\hline
\end{tabular}

* Expressed as milligrams per milliliter of plasma. HDL ( $d$ $1.09-1.21 \mathrm{~g} / \mathrm{ml}$ ) was isolated quantitatively from $5 \mathrm{ml}$ of plasma by two successive ultracentrifugations at $4^{\circ} \mathrm{C}$.

$\$$ Not done.

\$ Study with an $80 \%$ carbohydrate diet.

"Study with nicotinic acid treatment.

I Analysis of effect of $80 \%$ carbohydrate diet in four paired studies by paired $t$ test.

terol, and phospholipid concentrations in plasma fell in every patient. Furthermore, the composition of HDL changed. The ratio of cholesterol:protein fell by a mean of $16 \%(P<0.05)$ from the baseline values and that of cholesterol: phospholipid fell by a mean of $17 \%(P<0.02)$. These changes suggest a smaller mean HDL particle size with carbohydrate feeding.

With nicotinic acid treatment, generally opposite changes were found in both subjects. The plasma concentration of HDL protein changed little, whereas HDL cholesterol and phospholipid concentrations rose. The ratio of cholesterol:protein rose by a mean of $18 \%$ over base-line values as the ratio of cholesterol:phospholipid rose by a mean of $14 \%$ over baseline values. These findings suggest a larger mean HDL particle size with nicotinic acid treatment.

In three pairs of studies, $\mathrm{HDL}_{2}$ and $\mathrm{HDL}_{3}$ were quantitated by analytical ultracentrifugation (34) (kindly performed by Dr. Frank Lindgren of the Donner Laboratory, University of California). In addition, in those studies HDL was isolated quantita- tively over the density ranges $1.063-1.09 \mathrm{~g} / \mathrm{ml}$ and $1.09-1.21 \mathrm{~g} / \mathrm{ml}$. Each isolation was performed by two successive ultracentrifugations of $5-\mathrm{ml}$ aliquots of plasma. The results of these studies are shown in Table IV, and representative analytical ultracentrifugation patterns are shown in Fig. 2. Both methods indicate that carbohydrate feeding produced a relative diminution in the larger, less dense HDL particles $\left(\mathrm{HDL}_{2}\right.$ and HDL of $\left.d=1.063-1.09 \mathrm{~g} / \mathrm{ml}\right)$, whereas nicotinic acid treatment had the opposite effect.

The composition of the protein moiety of HDL in six of the subjects as determined by Sephadex G-200

TABLE III

Percent Apoprotein Composition of HDL $(1.09-1.21 \mathrm{~g} / \mathrm{ml})$

\begin{tabular}{|c|c|c|c|c|c|c|}
\hline Study & FX 1* & $\begin{array}{c}\text { FX } 2 \\
(\text { apoA-I) }\end{array}$ & $\begin{array}{c}\text { FX 3 } \\
\text { (apoA-II) }\end{array}$ & FX 4 & $\mathrm{FX} 2 / \mathrm{FX} 3$ & $\mathrm{FX} 2+\mathrm{FX} 3$ \\
\hline M. S. & 13.1 & 62.7 & 20.4 & 3.9 & 3.07 & 83.1 \\
\hline M. S. .hc & 11.0 & 60.3 & 24.7 & 3.9 & 2.44 & 85.0 \\
\hline D. M. & 6.3 & 69.4 & 20.3 & 3.9 & 3.42 & 89.7 \\
\hline D. $\mathrm{M}_{\cdot \mathrm{hc}} \ddagger$ & 9.5 & 65.0 & 21.3 & 4.1 & 3.05 & 86.3 \\
\hline W. G. & 8.3 & 58.1 & 21.2 & 12.5 & 2.74 & 79.3 \\
\hline W. G.het & 7.7 & 59.1 & 25.4 & 7.8 & 2.33 & 84.5 \\
\hline S. M. & 4.8 & 75.2 & 15.3 & 4.6 & 4.92 & 90.5 \\
\hline S. $M_{\cdot h c} \sharp$ & 4.5 & 66.3 & 24.6 & 4.7 & 2.70 & 90.9 \\
\hline M. H. & 3.8 & 71.5 & 20.3 & 4.5 & 3.52 & 91.8 \\
\hline$M . H_{\cdot_{n}} \S$ & 4.1 & 70.9 & 19.9 & 5.2 & 3.56 & 90.8 \\
\hline K. J. & 5.4 & 66.7 & 20.6 & 7.2 & 3.24 & 87.3 \\
\hline K. J.n $\S$ & 3.0 & 68.7 & 19.5 & 8.7 & 3.52 & 88.2 \\
\hline T. P. 1 & 8.7 & 66.8 & 12.4 & 12.1 & 5.39 & 79.2 \\
\hline T. P. 2 & 4.8 & 69.3 & 14.9 & 11.0 & 4.65 & 84.2 \\
\hline D. D. 1 & 5.8 & 61.4 & 20.7 & 12.2 & 2.97 & 82.1 \\
\hline D. D. 2 & 5.9 & 61.7 & 22.7 & 9.7 & 2.72 & 84.4 \\
\hline$P^{\sharp}$ & NS & NS & $<0.1$ & NS & NS & NS \\
\hline
\end{tabular}

Percent distribution of HDL protein in paired studies as determined by Sephadex G-200 (superfine) chromatography. HDL-2 $(d=1.063-1.125 \mathrm{~g} / \mathrm{ml})$ was isolated from the plasma of volunteers T. P. and D. D. and subjected to duplicate column runs and analyses to test the precision of this technique for determining apoHDL composition.

* Fraction 1 (FX 1) contains high molecular weight constituents and perhaps also aggregated forms of apoA-I and apoA-II. Fraction 2 (FX 2) contains apoA-I. Fraction 3 (FX 3) contains apoA-II. Fraction 4 (FX 4) contains $\mathrm{C}$ peptides, but is significantly contaminated with apoA-I and apoA-II as determined by SDS gel electrophoresis.

‡ Study with a high carbohydrate diet.

\$ Study with nicotinic acid treatment.

"Analysis of the effect of an $80 \%$ carbohydrate diet in paired studies by paired $t$ test. 
TABLE IV

Distribution of Mass over the HDL Density Range

\begin{tabular}{lll}
\hline Subject & $\begin{array}{c}\text { Mass ratio } \\
\mathrm{HDL}_{2}: \mathrm{HDL}_{3}\end{array}$ & $\begin{array}{c}\text { Protein ratio } \\
\text { 1.063-1.09 HDL:1.09-1.21 HDL }\end{array}$ \\
\hline S. M. & 0.54 & 0.16 \\
S. M.hc ${ }^{*}$ & 0.12 & 0.075 \\
M. H. & 0.087 & 0.064 \\
M. H.n $\$$ & 0.59 & 0.11 \\
K. J. & 0.35 & 0.11 \\
K. J.n & 0.67 & 0.15
\end{tabular}

The concentrations of $\mathrm{HDL}_{2}\left(\mathrm{~S}_{\mathrm{f}}^{\circ} 0-3.5\right)$ and $\mathrm{HDL}_{3}\left(\mathrm{~S}_{\mathrm{f}}^{\circ} 3.5-9.0\right)$ were assessed by analytical ultracentrifugation. HDL was isolated quantitatively over the density ranges $1.063-1.09 \mathrm{~g} / \mathrm{ml}$ and $1.09-1.21 \mathrm{~g} / \mathrm{ml}$ by preparative ultracentrifugation as described in the text.

* Study with an $80 \%$ carbohydrate diet.

I Study with nicotinic acid treatment.

(superfine) chromatography is shown in Table III. A mean of $86.6 \%$ (SD 3.4) of the protein eluted as apoA-I or apoA-II (range 79.3-91.8\%). The remainder was approximately evenly divided between the void and C-peptide peaks in all subjects except for M. S., where a mean of $12.1 \%$ of the protein eluted at the void volume and only $2.8 \%$ with the $\mathrm{C}$-peptides. The mean ratio of apoA-I: apoA-II with a balanced diet and no drug therapy was 3.49 (SD 0.48); there

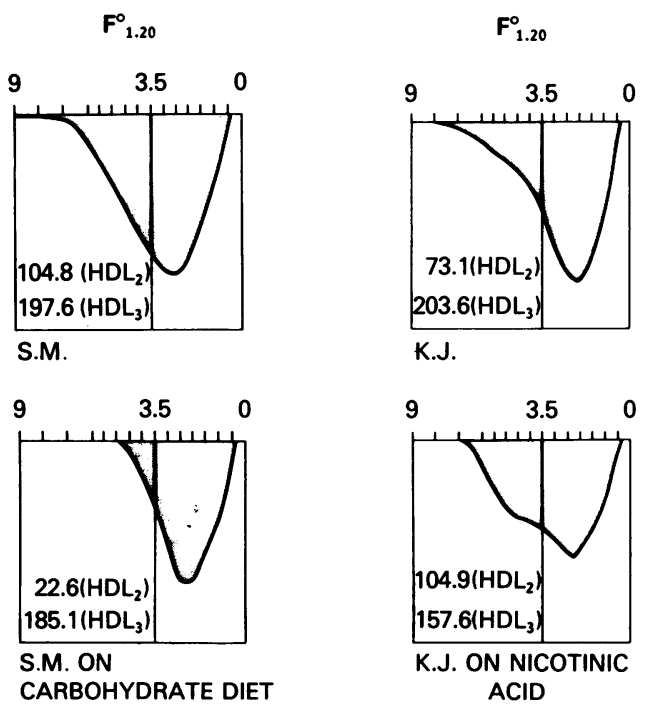

FIGURE 2 Analytical ultracentrifugation patterns of HDL in two pairs of studies, before and during the $80 \%$ carbohydrate diet (S. M.), and before and during nicotinic acid treatment (M. H.). $\mathbf{F o}_{1.20}$ refers to ultracentrifugal flotation rate with a background salt $d$ of $1.20 \mathrm{~g} / \mathrm{ml} \mathrm{HDL}_{2}$ is composed of lipoproteins with $\mathrm{Fo}_{1.20}$ 3.5-9.0; $\mathrm{HDL}_{3}$ is composed of lipoproteins with $\mathrm{Fo}_{\mathbf{1 . 2 0}} 0-3.5$. was a considerable range (2.74-4.92). With a high carbohydrate diet, the apoA-I:apoA-II ratio fell in every case, but the fall was not statistically significant. The apoA-II content of HDL protein rose in each case (mean change, $26 \%$ of base line and this change was of borderline statistical significance $[P<0.1]$ ). Conversely, with nicotinic acid treatment, the ratio of apoA-I:apoA-II rose slightly in both subjects, the mean elevation being $4.9 \%$ from the base-line value. If all the paired studies are analyzed together by the nonparametric sign test under the assumption that nicotinic acid treatment is the inverse perturbation of a high carbohydrate diet, the change in the ratio of apoA-I:apoA-II is statistically significant $(P<0.05)$.

Distribution of radioactivity in lipoprotein classes. After injection of ${ }^{125}$ I-HDL, virtually all radioactivity remained in the density range $1.063-1.21 \mathrm{~g} / \mathrm{ml}$ for the entire duration of each study. This was determined on all days when the subjects were plasmapheresed. A mean of $1.0 \%$ (SD 0.9 ) of the radioactivity was found in the density fraction $<1.063$ during the 1 st wk of the studies, and $1.5 \%$ (SD 1.0) during the succeeding days. A mean of 5.5\% (SD 1.2) of radioactivity was found in the density fraction $>1.21 \mathrm{~g} / \mathrm{ml}$ during the 1st week and 5.8\% (SD 2.9) during the succeeding days. These latter measurements probably represent overestimates because repeated ultracentrifugation removed apoA-I from HDL to the $d 1.21 \mathrm{~g} / \mathrm{ml}$ fraction of plasma. (Radioactivity in the $d>1.21 \mathrm{~g} / \mathrm{ml}$ fraction was determined after the samples had previously been centrifuged at $d 1.063 \mathrm{~g} / \mathrm{ml}$ ).

Kinetic analysis. After injection of the ${ }^{125} \mathrm{I}-\mathrm{HDL}$, plasma radioactivity decayed in a complex fashion. Fig. 3 presents representative decay curves. In paired studies, carbohydrate feeding was associated with more rapid decay compared to the balanced diet periods. Conversely, nicotinic acid treatment was associated with a slower decay in both pairs of studies.

The decay of specific activity of apoA-I and apoA-II in each turnover study is shown in Table V. Decay curves for two representative pairs of studies are shown in Fig. 4. The curves for the two peptides appear parallel in all studies. This holds under control conditions of a balanced diet as well as carbohydrate feeding and nicotinic acid treatment, two distinct perturbations of HDL catabolism, suggesting that apoA-I and apoA-II of HDL are not catabolized separately as are the B- and C-peptides of VLDL, but are catabolized together.

The decay of plasma radioactivity and the appearance of urinary radioactivity were analyzed with the SAAM computer program of Berman and Weiss (35, 36). The multicompartmental model which was developed to provide the best least squares fit for the data is shown in Fig. 5. This model also gave the best fit for the decay of specific activity of apoA-I and 

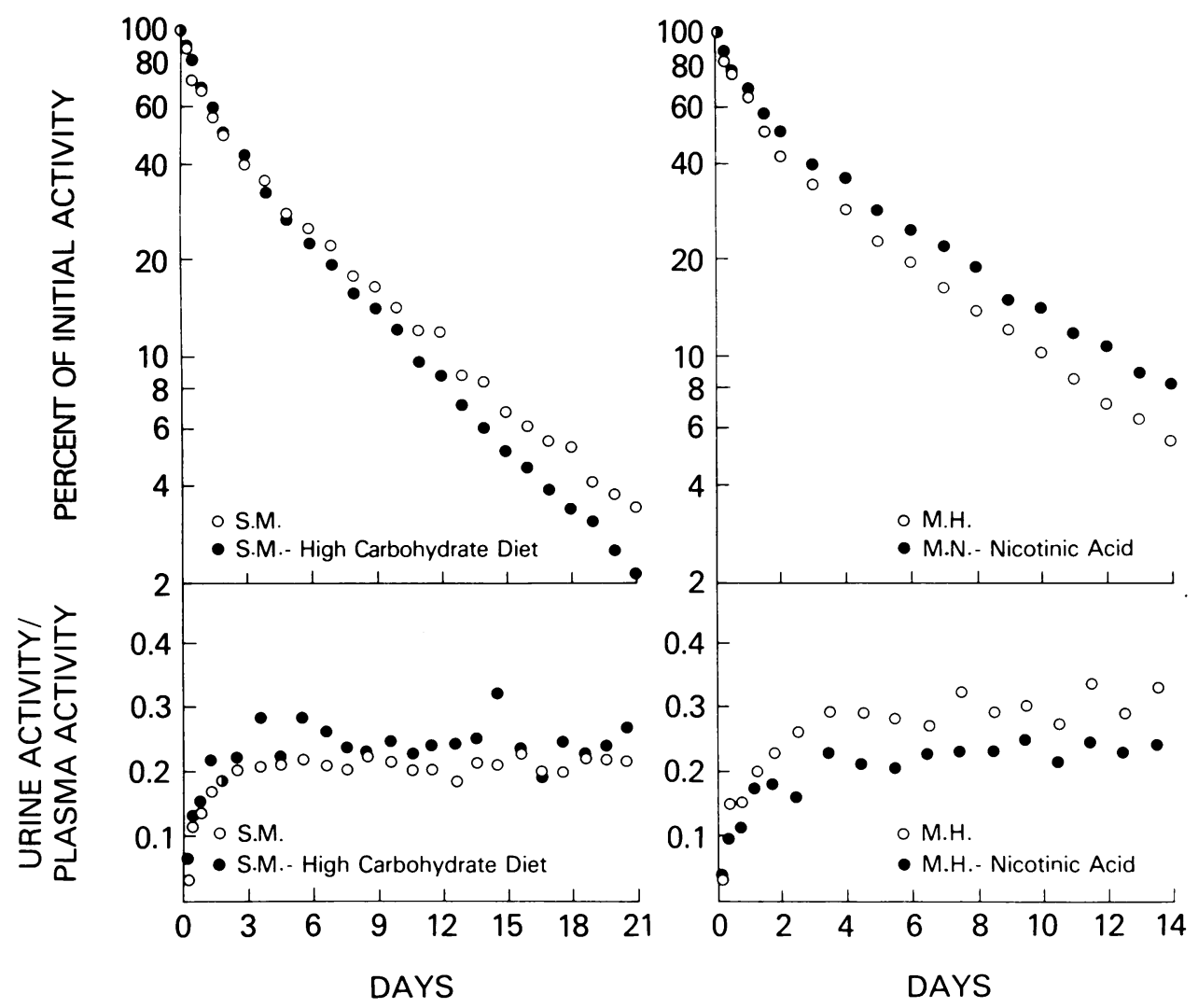

FIGURE 3 Decay of plasma radioactivity and appearance of urinary radioactivity in two representative pairs of studies. The open circles represent control studies. The closed circles represent studies with an $80 \%$ carbohydrate diet or nicotinic acid treatment. Urine activity/plasma activity denotes the rate of urinary excretion of radioactivity per $24 \mathrm{~h}$ divided by the mean plasma radioactivity for each collection period.

apoA-II. The compartments are denoted by arabic numbers and the rate constants by $L(i, j)$. Synthetic rate of HDL protein is represented as $U$ (1). All masses, synthetic rates, and fluxes are based on the HDL ( $d 1.09-1.21 \mathrm{~g} / \mathrm{ml}$ ) protein concentrations presented in Table II. The model is characterized by two primary compartments and a plasma compartment (1) which is exchanged with a second compartment (2) which is probably extravascular.

Although the decay of plasma radioactivity could be simulated by models with catabolism occurring from either compartment or from both, catabolism from both compartments had to be postulated in order for the model to be consistent with the observed pattern of excretion of urinary radioactivity. It was found that a model postulating all catabolism from the plasma compartment predicted more rapid early urinary excretion of radioactivity and too little late excretion compared to the observed pattern of excretion. The converse was found with a model postulating all catabolism from the second compartment. The model was able to fit the plasma and urine data best, however, when it permitted catabolism through both compartments. This model is not the only model capable of simulating the data. It is, however, the simplest one (the only two-compartmental model that can fit the data). ${ }^{2}$

Compartment 3 represents iodide, assumed to have a rate constant of 2 days $^{-1}$ for removal from the body into the urine (38). A mean of $2.4 \%$ of the injected radioactivity is required kinetically as iodide contamination. This compares with a mean of $0.89 \%$ of free ${ }^{125} \mathrm{I}$ found experimentally by precipitation with TCA. A mean of $1.1 \%$ of the injected radioactivity (range $0-4.7 \%$ ) seems to be degraded rapidly (about 2 days $^{-1}$ ), and is probably a combination of artifactually altered material and labeled lipid. A small amount of the radioactivity could not be accounted

${ }^{2}$ Additional HDL turnover studies performed in homozygous and heterozygous patients with Tangier disease showed nearly all ${ }^{125}$ I-HDL (autologous or from a normal volunteer) to be catabolized via the plasma compartment (37). Thus, it seems highly unlikely that the earlier excreted radioactivity represents denatured or otherwise altered HDL. 
TABLE V

Decay of Specific Activity in ApoA-I (A-I) and ApoA-II (A-II)

\begin{tabular}{|c|c|c|c|c|c|c|c|c|c|c|}
\hline \multirow[b]{2}{*}{ Subject } & & \multicolumn{9}{|c|}{ Days } \\
\hline & & 0 & 1 & 4 & 7 & 10 & 12 & 14 & 18 & 21 \\
\hline \multirow[t]{2}{*}{ M. S. } & A-I & 100 & 54.6 & 33.6 & 18.2 & 19.5 & 9.79 & 7.39 & & \\
\hline & A-II & 100 & 59.1 & 37.5 & 20.6 & 22.4 & 10.8 & 10.5 & & \\
\hline \multirow[t]{2}{*}{ M. S.he ${ }^{*}$} & A-I & 100 & 62.2 & 29.8 & 17.4 & 11.7 & 8.54 & 6.58 & & \\
\hline & A-II & 100 & 61.8 & 29.8 & 17.4 & 11.1 & 7.83 & 6.41 & & \\
\hline \multirow[t]{2}{*}{ D. $\mathrm{M}$. } & A-I & 100 & 63.0 & 33.3 & 24.8 & 14.6 & 9.63 & 8.04 & & \\
\hline & A-II & 100 & 77.0 & 35.5 & 21.7 & 13.6 & 11.8 & 9.83 & & \\
\hline \multicolumn{2}{|c|}{ D. $\mathbf{M}_{\cdot \mathrm{hc}}{ }^{*} \mathbf{A}-\mathbf{I}$} & 100 & 63.4 & 26.1 & 13.8 & 8.34 & 6.31 & 4.63 & & \\
\hline & A-II & 100 & 59.8 & 24.6 & 13.7 & 7.70 & 6.45 & 5.01 & & \\
\hline \multirow[t]{2}{*}{ W. G. } & A-I & 100 & 57.6 & 26.3 & 16.5 & 9.80 & 7.34 & 5.95 & & \\
\hline & A-II & 100 & 59.2 & 19.2 & 16.0 & 11.3 & 8.44 & 6.99 & & \\
\hline \multirow[t]{2}{*}{ W. G.hc ${ }^{*}$} & A-I & 100 & 63.1 & 26.8 & 14.9 & 8.97 & 6.32 & 4.75 & & \\
\hline & A-II & 100 & 66.5 & 31.7 & 16.8 & 10.3 & 8.67 & 6.00 & & \\
\hline \multirow[t]{2}{*}{ S. M. } & A-I & 100 & 65.1 & 34.5 & 19.1 & 13.7 & 10.2 & 7.76 & 4.66 & 3.57 \\
\hline & A-II & 100 & 74.4 & 34.4 & 22.4 & 15.0 & 10.5 & 7.78 & 5.38 & 3.30 \\
\hline \multirow[t]{2}{*}{ S. $M_{\cdot h c^{*}}$} & A-I & 100 & 63.8 & 31.2 & 16.0 & 13.0 & 8.54 & 6.91 & 2.77 & 1.98 \\
\hline & A-II & 100 & 63.0 & 33.2 & 18.6 & 12.6 & - & 6.08 & 2.68 & 2.43 \\
\hline \multirow[t]{2}{*}{ K. J. } & A-I & 156 & 100 & 49.8 & 31.0 & 21.1 & 14.8 & 12.3 & & \\
\hline & A-II & 130 & 100 & 48.7 & 31.7 & 22.1 & 15.0 & 12.6 & & \\
\hline \multirow[t]{2}{*}{$\mathrm{K} \cdot \mathrm{J} \cdot \mathrm{n} \ddagger$} & A-I & 100 & 65.2 & 37.0 & 24.4 & 15.9 & 13.0 & 9.70 & & \\
\hline & A-II & 100 & 73.9 & 36.2 & 25.8 & 16.3 & 15.6 & 9.57 & & \\
\hline \multirow[t]{2}{*}{ M. H. } & A-I & 100 & 60.2 & 28.3 & 16.0 & 10.2 & 7.12 & 5.36 & & \\
\hline & A-II & 100 & 63.9 & 30.9 & 17.5 & 11.0 & 8.55 & 6.20 & & \\
\hline \multirow[t]{4}{*}{ M. $H_{\cdot n} \hbar$} & A-I & 100 & 60.8 & 30.4 & 18.9 & 12.8 & 9.91 & 7.01 & & \\
\hline & A-II & 100 & 57.5 & 32.1 & 19.9 & 14.3 & 9.93 & 8.57 & & \\
\hline & & \multicolumn{6}{|c|}{ Days } & & & \\
\hline & & 0 & 1 & 5 & 9 & 13 & 19 & & & \\
\hline \multirow[t]{2}{*}{ K. R. } & A-I & 100 & 70.6 & 30.9 & 18.3 & & & & & \\
\hline & A-II & 100 & 71.5 & 33.9 & 21.0 & & & & & \\
\hline \multirow[t]{2}{*}{ J. M. } & A-I & 100 & 53.4 & 24.4 & - & 9.34 & 4.15 & & & \\
\hline & A-II & 100 & 63.7 & 26.7 & - & 12.1 & 4.52 & & & \\
\hline
\end{tabular}

Decay of specific activity of apoA-I and apoA-II has been normalized in each study except K. J. to the initial sampling point at day 0 (10 min after injection of ${ }^{125} \mathrm{I}-\mathrm{HDL}$ ). Parallel decay of the two peptides was better demonstrated in K. J. by normalizing to values 1 day after injection.

* Study with high carbohydrate diet.

\# Study with nicotinic acid treatment.

for in urine and was assumed to be lost from compartment 2 via a pathway with a rate constant $L(0,2)$.

Model parameters in each study are shown in Table VI. In the subjects who underwent paired studies it was possible to obtain an optimal least squares fit to the data while still keeping $\mathrm{L}(2,1), \mathrm{L}(1,2)$, and $\mathrm{L}(0,2)$ fixed for each subject. It can be seen that with a balanced diet and without nicotinic acid treatment a mean of $61.9 \%$ of the HDL protein mass was found in the intravascular compartment. The mean synthetic rate of HDL protein was $8.51 \mathrm{mg} / \mathrm{kg}$ per day on a balanced diet. Carbohydrate feeding produced no significant change in the synthetic rate (mean change $1.7 \%$ of base line, $P>0.20$ ). In the two studies with nicotinic acid treatment, on the other hand, that perturbation was associated with a mean $11 \%$ fall in $U(1)$.

The most striking kinetic changes with carbohydrate feeding and with nicotinic acid treatment occurred in the catabolic rate constants $L(3,1)$ and $L(3,2)$. In each of the three subjects who adhered well to the isocaloric high carbohydrate diet (W. G. did not adhere 

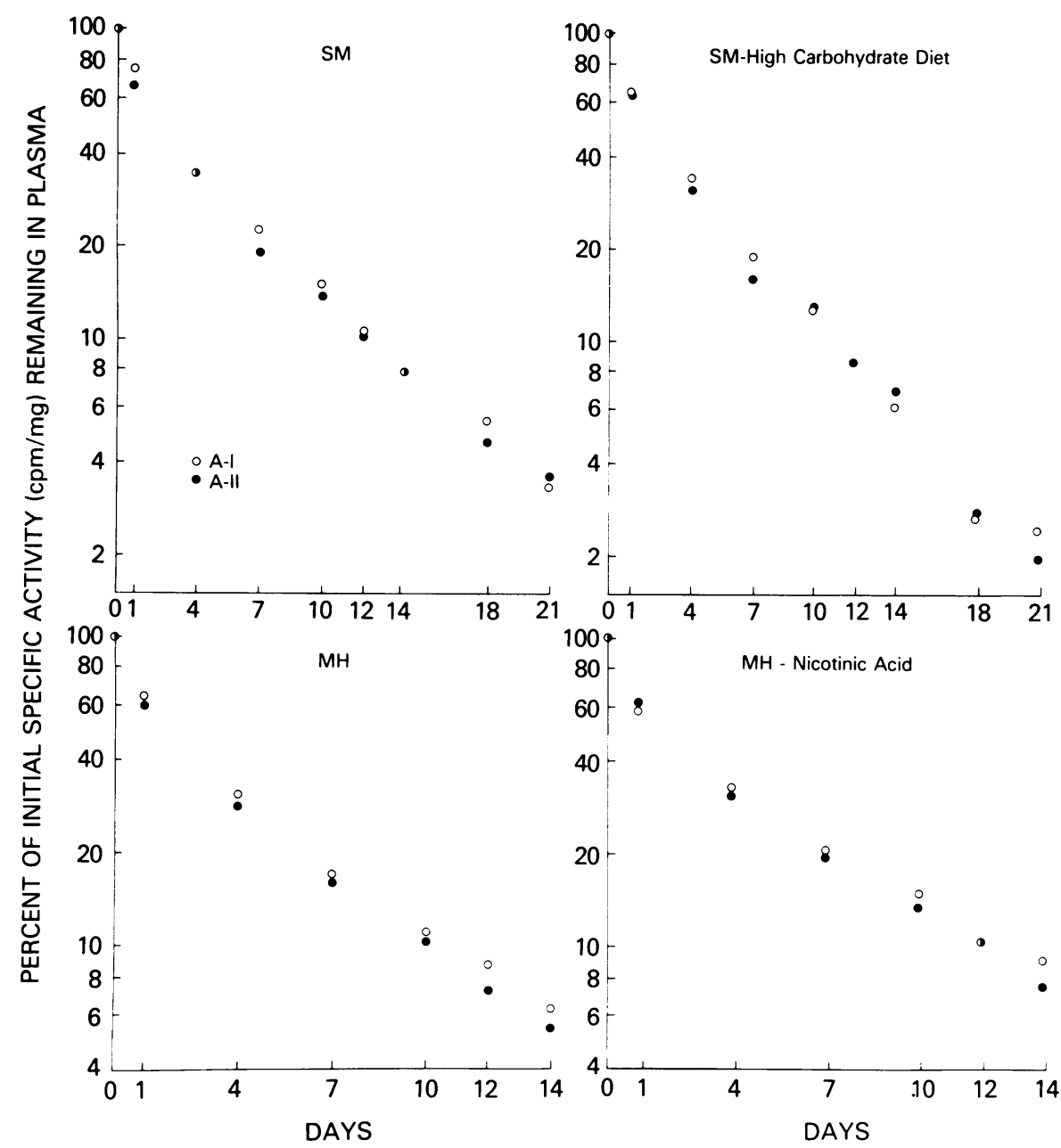

FIgURE 4 Decay of specific activity in apoA-I and apoA-II in two pairs of studies. All values are normalized to the first sample obtained, $10 \mathrm{~min}$ after injection of ${ }^{125} \mathrm{I}-\mathrm{HDL}$. The closed circles represent specific activity of apoA-I (A-I); the open circles represent specific activity of apoA-II (A-II). The studies marked S. M. and M. H. were performed with a balanced diet and without nicotinic acid treatment. The study labeled S. M.-high carbohydrate diet was performed with an $80 \%$ carbohydrate diet. The study labeled M. H.-nicotinic acid was performed with nicotinic acid treatment.

well and was in negative caloric balance during his high carbohydrate study), the rate of catabolism from the intravascular compartment $\mathrm{L}(3,1)$ rose substantially with carbohydrate feeding (mean rise $52.5 \%$ of base line). A converse effect was observed in both subjects with nicotinic acid treatment where $\mathrm{L}(3,1)$ fell (mean fall $42.2 \%$ ). With W. G., who adhered poorly to the high carbohydrate diet and was in negative caloric balance, there was practically no change in $\mathrm{L}(3,1)$. Because of the lack of change in $\mathrm{L}(3,1)$ with W. G., statistical significance was not obtained when data from all four subjects with paired carbohydrate studies were analyzed with a paired $t$ test. The three adherents unfortunately do not constitute a large enough group to be amenable to statistical analysis. However, in view of the consistency of the results among adherents (as well as the reciprocal changes seen with nicotinic acid treatment), these carbohydrate-induced changes in HDL metabolism do appear to represent a genuine trend. The rate of catabolic activity from the extravascular compartment varied less consistently with carbohydrate feeding. With nicotinic acid treatment, L $(3,2)$ rose in both subjects; the mean change was $28 \%$ above base line.

\section{DISCUSSION}

These studies of the turnover of the major HDL peptides show that apoA-I and apoA-II are catabolized together under normal and perturbed conditions. They 


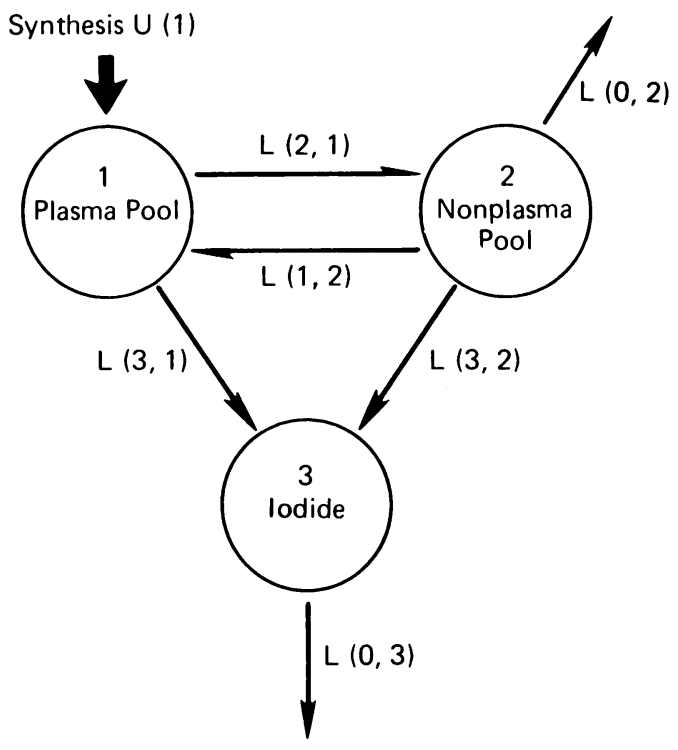

FIGURE 5 Kinetic model of metabolism of the major HDL apoproteins. Compartment 1 is plasma. Compartment 2 is nonplasma. Compartment 3 represents iodide. Rate constants are denoted $\mathrm{L}(i, j)$. Synthetic rate of HDL apoprotein is denoted $\mathrm{U}(1)$.

further demonstrate that the effects on HDL metabolism of an $80 \%$ carbohydrate diet and of nicotinic acid treatment are reciprocal in many respects. Mathematical modeling of the kinetic data revealed that catabolism occurs through both intravascular and extravascular compartments. Furthermore, these two catabolic pathways appear to be regulated reciprocally.

Studies of the turnover of HDL in man have appeared in the past. In 1958 Gitlin et al. (39) reported on the turnover of VLDL, LDL, and HDL. They found that the half-lives of ${ }^{125} \mathrm{I}-\mathrm{HDL}$ in two normals

TABLE VI

Kinetic Parameters of the Turnover Studies*

\begin{tabular}{|c|c|c|c|c|c|c|c|c|c|c|c|c|c|}
\hline Study & $\begin{array}{l}\text { Synthesis } \\
\text { rate } \\
U(1)\end{array}$ & $\begin{array}{c}\text { Plasma } \\
\text { FCR } \\
\mathrm{L}(3,1)\end{array}$ & $\begin{array}{c}\text { Nonplasma } \\
\text { FCR (major) } \\
\mathrm{L}(3,2)\end{array}$ & $\begin{array}{c}\text { Nonplasma } \\
\text { FCR (minor) } \\
\mathrm{L}(0,2)\end{array}$ & $\begin{array}{c}\text { Exchange } \\
\text { FCR }(2,1) \\
\mathrm{L}(2,1)\end{array}$ & $\begin{array}{c}\text { Exchange } \\
\text { FCR }(1,2) \\
\mathrm{L}(1,2)\end{array}$ & $\begin{array}{c}\text { Plasma } \\
\text { flux } \\
\mathbf{R}(3,1)\end{array}$ & $\begin{array}{c}\text { Nonplasma } \\
\text { flux (major) } \\
\mathbf{R}(3,2)\end{array}$ & $\begin{array}{c}\text { Nonplasma } \\
\text { flux (minor) } \\
\mathbf{R}(0,2)\end{array}$ & $\begin{array}{c}\text { Plasma } \\
\text { mass } \\
\mathbf{M}(1)\end{array}$ & $\begin{array}{c}\text { Nonplasma } \\
\text { mass } \\
\mathbf{M}(2)\end{array}$ & $\begin{array}{l}\text { Plasma } \\
\text { volume }\end{array}$ & $\begin{array}{l}\text { Percent of } \\
\text { total HDL in } \\
\text { plasma space }\end{array}$ \\
\hline & $m g / k g / d a y$ & dayys $s^{-1}$ & $\operatorname{dalys} s^{-1}$ & days $s^{-1}$ & $d a ! s^{-1}$ & days $s^{-1}$ & $m g / k g / d a$ & mg/kg/da! & $m g / k g / d a ! !$ & $m g / k g$ & $m g / k g$ & $m l$ & $\%$ \\
\hline
\end{tabular}

Single

\begin{tabular}{|c|c|c|c|c|c|c|c|c|c|c|c|c|}
\hline J. M. & 8.04 & 0.066 & 0.119 & 0.056 & 0.406 & 0.375 & 2.72 & 3.64 & 1.70 & 41.3 & 30.6 & 3,157 \\
\hline K. R. & 7.81 & 0.120 & 0.081 & 0.017 & 0.250 & 0.370 & 5.45 & 1.98 & 0.41 & 45.4 & 24.3 & 2.399 \\
\hline
\end{tabular}

Paired, before and during high carbohydrate diet

\begin{tabular}{|c|c|c|c|c|c|c|c|c|c|c|c|c|c|}
\hline M. S. & 4.40 & 0.109 & 0.118 & 0.016 & 0.244 & 0.337 & 2.68 & 1.50 & 0.20 & 24.6 & 12.7 & 2,572 & 66.0 \\
\hline M. S.hc & 4.40 & 0.153 & 0.083 & 0.016 & 0.244 & 0.337 & 3.23 & 0.98 & 0.19 & 21.1 & 11.8 & 2,710 & 64.1 \\
\hline $\begin{array}{l}\text { D. M. } \\
\text { D. M.hc }\end{array}$ & $\begin{array}{l}7.36 \\
7.62\end{array}$ & $\begin{array}{l}0.095 \\
0.189\end{array}$ & $\begin{array}{l}0.177 \\
0.116\end{array}$ & $\begin{array}{l}0.022 \\
0.022\end{array}$ & $\begin{array}{l}0.331 \\
0.331\end{array}$ & $\begin{array}{l}0.395 \\
0.395\end{array}$ & $\begin{array}{l}3.40 \\
5.25\end{array}$ & $\begin{array}{l}3.50 \\
2.01\end{array}$ & $\begin{array}{l}0.44 \\
0.38\end{array}$ & $\begin{array}{l}35.6 \\
27.8\end{array}$ & $\begin{array}{l}19.8 \\
17.3\end{array}$ & $\begin{array}{l}2,584 \\
2,679\end{array}$ & $\begin{array}{l}64.3 \\
61.0\end{array}$ \\
\hline $\begin{array}{l}\text { W. G. } \\
\text { W. G.hc }\end{array}$ & $\begin{array}{l}5.69 \\
5.26\end{array}$ & $\begin{array}{l}0.109 \\
0.108\end{array}$ & $\begin{array}{l}0.156 \\
0.145\end{array}$ & $\begin{array}{l}0.003 \\
0.003\end{array}$ & $\begin{array}{l}0.331 \\
0.331\end{array}$ & $\begin{array}{l}0.245 \\
0.245\end{array}$ & $\begin{array}{l}2.59 \\
2.44\end{array}$ & $\begin{array}{l}3.04 \\
2.76\end{array}$ & $\begin{array}{l}0.06 \\
0.06\end{array}$ & $\begin{array}{l}23.8 \\
22.6\end{array}$ & $\begin{array}{l}19.5 \\
19.0\end{array}$ & $\begin{array}{l}2,494 \\
2,466\end{array}$ & $\begin{array}{l}55.0 \\
54.3\end{array}$ \\
\hline $\begin{array}{l}\text { S. M. } \\
\text { S. M.hc }\end{array}$ & $\begin{array}{l}10.20 \\
10.10\end{array}$ & $\begin{array}{l}0.137 \\
0.163\end{array}$ & $\begin{array}{l}0.076 \\
0.098\end{array}$ & $\begin{array}{l}0.034 \\
0.034\end{array}$ & $\begin{array}{l}0.213 \\
0.213\end{array}$ & $\begin{array}{l}0.337 \\
0.337\end{array}$ & $\begin{array}{l}7.38 \\
7.35\end{array}$ & $\begin{array}{l}1.95 \\
2.02\end{array}$ & $\begin{array}{l}0.87 \\
0.70\end{array}$ & $\begin{array}{l}53.9 \\
45.1\end{array}$ & $\begin{array}{l}25.7 \\
20.5\end{array}$ & $\begin{array}{l}2,235 \\
2,317\end{array}$ & $\begin{array}{l}67.7 \\
68.8\end{array}$ \\
\hline \multicolumn{14}{|c|}{ aired, before and during nicotinic acid treatment } \\
\hline $\begin{array}{l}\text { M. H. } \\
\text { M. H.n } \S\end{array}$ & $\begin{array}{l}12.40 \\
10.90\end{array}$ & $\begin{array}{l}0.158 \\
0.117\end{array}$ & $\begin{array}{l}0.117 \\
0.131\end{array}$ & $\begin{array}{l}0.019 \\
0.019\end{array}$ & $\begin{array}{l}0.300 \\
0.300\end{array}$ & $\begin{array}{l}0.341 \\
0.341\end{array}$ & $\begin{array}{l}8.03 \\
6.14\end{array}$ & $\begin{array}{l}3.74 \\
4.21\end{array}$ & $\begin{array}{l}0.60 \\
0.60\end{array}$ & $\begin{array}{l}50.8 \\
52.5\end{array}$ & $\begin{array}{l}32.0 \\
32.1\end{array}$ & $\begin{array}{l}3,903 \\
3,929\end{array}$ & $\begin{array}{l}61.4 \\
62.1\end{array}$ \\
\hline $\begin{array}{l}\text { K. J. } \\
\text { K. J.nt }\end{array}$ & $\begin{array}{l}9.65 \\
8.78\end{array}$ & $\begin{array}{l}0.110 \\
0.046\end{array}$ & $\begin{array}{l}0.134 \\
0.193\end{array}$ & $\begin{array}{l}0.023 \\
0.023\end{array}$ & $\begin{array}{l}0.347 \\
0.347\end{array}$ & $\begin{array}{l}0.340 \\
0.340\end{array}$ & $\begin{array}{l}4.83 \\
2.22\end{array}$ & $\begin{array}{l}4.10 \\
5.85\end{array}$ & $\begin{array}{l}0.72 \\
0.71\end{array}$ & $\begin{array}{l}43.9 \\
48.6\end{array}$ & $\begin{array}{l}30.6 \\
30.3\end{array}$ & $\begin{array}{l}2,439 \\
2,772\end{array}$ & $\begin{array}{l}58.9 \\
61.6\end{array}$ \\
\hline \multicolumn{14}{|c|}{ Mean control values, balanced diet without nicotinic acid } \\
\hline$P^{\|}$ & $\begin{array}{l}8.20 \\
\text { NS }\end{array}$ & $\begin{array}{c}0.113 \\
\text { NS }\end{array}$ & $\begin{array}{c}0.122 \\
\text { NS }\end{array}$ & 0.024 & 0.303 & 0.343 & $\begin{array}{l}4.64 \\
\text { NS }\end{array}$ & $\begin{array}{l}2.93 \\
\text { NS }\end{array}$ & $\begin{array}{l}0.63 \\
\text { NS }\end{array}$ & $\begin{array}{l}39.9 \\
<0.1\end{array}$ & $\begin{array}{l}24.4 \\
\text { NS }\end{array}$ & $\begin{array}{c}2,722 \\
\text { NS }\end{array}$ & $\begin{array}{l}62.0 \\
\text { NS }\end{array}$ \\
\hline
\end{tabular}

* See Fig. 5 and text for description of kinetic model and designation of specific compartments. Mg refers to milligrams HDL protein. FCR is fractional catabolic rate. Plasma volume or initial space of distribution is given in milliliters.

\$ Study with high carbohydrate diet.

$\$$ Study with nicotinic acid treatment.

"Analysis of effect of $80 \%$ carbohydrate diet in paired studies by paired $t$ test. 
were 4.8 and 4.4 days as calculated from the terminal slope of plasma decay curves.

Scanu and Hughes (40) studied the turnover of ${ }^{131}$ I-HDL in two subjects. They found that virtually all of the radioactivity remained in the HDL density range throughout the 16 days of study and that the half-life of the terminal portion of the plasma decay was 4.5 and 4.2 days. Furman et al. (41) in the only other report of HDL turnover in man obtained similar results. Approximately $60 \%$ of plasma radioactivity remained in the HDL density range. The plasma half-life of HDL in their subjects was somewhat shorter than in the subjects of Scanu and Hughes (40) or of Gitlin et al. (39), averaging 3.5 days in the normal subjects. Furthermore, they found similar results after injecting ${ }^{125} \mathrm{I}$-apoHDL as with ${ }^{125} \mathrm{I}$-HDL. In comparison, the mean half-life of the terminal portion of decay in our eight normal volunteers. during treatment with a balanced diet and without nicotinic acid was 5.8 days (SD 1.3). The mean halflife during ingestion of an isocaloric $80 \%$ carbohydrate diet in four of these subjects was 4.8 days, whereas in the two subjects studied with nicotinic acid treatment it was 5.7 days.

These early studies were performed before knowledge of the heterogeneity of the protein moiety of HDL. Although the disappearance of labeled protein was followed in each case, the possibility of disparate catabolism of the major HDL peptides was not investigated. Divergent metabolic pathways of the B and $C$ peptides of VLDL have been clearly demonstrated. Because apoA-I and apoA-II have distinct primary structures and functional roles, it might be suspected that they also have distinct metabolic fates.

Eisenberg et al. (16) investigated the metabolic fate of human ${ }^{125} \mathrm{I}-\mathrm{HDL}$ injected into the rat. It was found that human apoA-I was removed from the circulation more slowly $\left(t_{\frac{1}{2}}=13 \mathrm{~h}\right)$ than was human apoA-II $\left(t_{\frac{1}{2}}=9 \mathrm{~h}\right)$. Furthermore, they reported that the major catabolic site for human and rat ${ }^{125}$ I-HDL in the rat was the liver.

The studies described here were carried out with the major objective of defining the metabolic relationship between apoA-I and apoA-II in man. The decay of specific radioactivity of apoA-I and apoA-II in ${ }^{125}$ I-HDL was measured directly in each study. This approach demonstrated that apoA-I and apoA-II of HDL are catabolized identically to one another under control as well as perturbed conditions.

These studies provide some insight into mechanisms by which carbohydrate feeding and nicotinic acid treatment influence HDL metabolism and suggest that the influence of these two perturbations is reciprocal in many respects.

With carbohydrate feeding the ratios of cholesterol: protein and cholesterol:phospholipid fell in each case. This suggests a smaller mean HDL particle size because available data indicate that HDL particles are spherical and are composed of an amphiphilic surface of protein, phospholipid, and unesterified cholesterol, and a hydrophobic core of cholesteryl ester and triglyceride (42-47). Most of the cholesterol in HDL is esterified (48). Furthermore, analytical ultracentrifugation in the studies of S. M. demonstrated that with carbohydrate feeding a larger portion of the total plasma HDL was found among the smaller, denser particles of $\mathrm{HDL}_{3}$. In all these respects, reciprocal changes were seen in both studies with nicotinic acid treatment.

Carbohydrate feeding resulted in a lower ratio of apoA-I:apoA-II, whereas nicotinic acid treatment yielded HDL with a slightly higher apoA-I:apoA-II ratio. Published reports of the apoA-I:apoA-II ratio in $\mathrm{HDL}_{2}$ compared to that in $\mathrm{HDL}_{3}$ are contradictory, indicating variously that it is higher in $\mathrm{HDL}_{2}(19$, $49,50)$, that it is lower in $\mathrm{HDL}_{2}(14)$, and that it is identical in these two subclasses of HDL (51). If the apoA-I:apoA-II ratio in $\mathrm{HDL}_{2}$ is higher than in $\mathrm{HDL}_{3}$, the changes in that ratio with carbohydrate feeding and nicotinic acid treatment may be attributed in part to the observed shift in the HDL density spectrum.

The changes in mean HDL particle size and apoprotein composition with carbohydrate feeding and nicotinic acid treatment may be the result of a qualitative change in either synthesis or catabolism. In the case of both perturbations, the altered apoA-I: apoA-II ratio in the face of identical decay rates for apoA-I and apoA-II speaks in favor of a qualitative change in HDL synthesis.

The kinetic modeling of decay of plasma radioactivity in combination with appearance of urinary radioactivity demonstrated catabolism from both plasma and nonplasma compartments. The plasma decay curves alone were consistent with all catabolism occurring via either compartment or a combination of them. These studies do not demonstrate the precise locations or distinct roles of the plasma and nonplasma catabolic sites. Furthermore, they do not permit us to identity the HDL synthetic entry site, and the choice of the plasma compartment as the synthetic entry site is arbitrary. The major conclusions, however, with respect to total synthetic rate and changes in patterns of catabolism are independent of the site of entry.

In all subjects who adhered well to the $80 \%$ carbohydrate diet, there was an increase in the fractional rate of catabolism from the intravascular compartment, whereas in both subjects undergoing nicotinic acid treatment, it fell. These changes in the catabolic rate from the intravascular compartment may be secondary to changes in the concentration or flux 
of VLDL. An $80 \%$ carbohydrate diet increases VLDL-triglyceride flux and concentration (52-54), whereas nicotinic acid treatment produces reciprocal effects (55). An inverse correlation has been noted between triglyceride and HDL levels, and the familial hypertriglyceridemias are associated with particularly low plasma levels of HDL (56). Furman et al. (41) reported a direct relationship between plasma triglyceride levels and the terminal rate of decay of intravenously injected ${ }^{131} \mathrm{I}-\mathrm{HDL}$. The triglyceride kinetics of their subjects were not studied. All this gives further support to the concept that elevation of the flux or concentration of plasma VLDL may be linked to an increased rate of catabolism of HDL from plasma.

\section{ACKNOWLEDGMENTS}

The authors wish to acknowledge the expert technical assistance of Ms. Elanne Smootz and Mrs. Leslie Jenkins, and thank Dr. Ernst J. Schaefer and Ms. Joy Lee Grant for assistance in the preparation of the manuscript.

\section{REFERENCES}

1. Eisenberg, S., D. W. Bilheimer, R. I. Levy, and F. T. Lindgren. 1973. On the metabolic conversion of human plasma very low density lipoprotein to low density lipoprotein. Biochim. Biophys. Acta. 326: 361-377.

2. Bilheimer, D. W., S. Eisenberg, and R. I. Levy. 1972. The metabolism of very low density lipoproteins. I. Preliminary in vitro and in vivo observations. Biochim. Biophys. Acta. 260: 212-221.

3. Havel, R. J., J. P. Kane, and M. L. Kashyap. 1973. Interchange of apolipoproteins between chylomicrons and high density lipoproteins during alimentary hyperlipemia in man. J. Clin. Invest. 52: 32-38.

4. Glomset, J. A., E. T. Janssen, R. Kennedy, and J. Dobbins. 1966. Role of plasma lecithin:cholesterol acyltransferase in the metabolism of high density lipoproteins. J. Lipid Res. 7: 638-648.

5. Fielding, C. J., and P. E. Fielding. 1971. Purification and substrate specificity of lecithin:cholesterol acyltransferase from human plasma. FEBS (Fed. Eur. Biochem. Soc.) Lett. 15: 355-358.

6. Scanu, A., J. Toth, C. Edelstein, and E. Stiller. 1969. Fractionation of human serum high density lipoprotein in urea solutions: evidence for polypeptide heterogeneity. Biochemistry. 8: 3309-3316.

7. Shore, B., and V. Shore. 1969. Isolation and characterization of polypeptides of human serum lipoproteins. Biochemistry. 8: 4510-4516.

8. Baker, H. N., T. Delahunty, A. M. Gotto, and R. Jackson. 1974. The primary structure of high density apolipoprotein-glutamine-I. Proc. Natl. Acad. Sci. U. S. A. 71: 3631-3634.

9. Brewer, H. B., S. E. Lux, R. Ronan, and K. M. John. 1972. Amino acid sequence of human apoLp-Gln-II (apoA-II), an apolipoprotein isolated from the high density lipoprotein complex. Proc. Natl. Acad. Sci.U.S.A. 69: $1304-1308$.

10. Fielding, C. J., V. Shore, and P. E. Fielding. 1972. A protein cofactor for lecithin:cholesterol acyltransferase. Biochem. Biophys. Res. Commun. 46: 1493-1498.
11. Levy, R. I., and D. S. Fredrickson. 1965. Heterogeneity of plasma high density lipoproteins. J. Clin. Invest. 44: 426-441.

12. Nichols, A. V., S. E. Lux, T. Forte, E. Gong, and R. I. Levy. 1972. Degradation products from human serum high density lipoproteins following dehydration by rotary evaporation and solubilization. Biochim. Biophys. Acta. 270: 132-148.

13. Fainaru, M., M. C. Glangeaud, and S. Eisenberg. 1975. Radioimmunoassay of human high density lipoprotein apoprotein A-I. Biochim. Biophys. Acta. 386: 432-443.

14. Albers, J. J., and F. Aladjem. 1971. Precipitation of ${ }^{125}$ I-labeled lipoproteins with specific polypeptide antisera: evidence for two populations with differing polypeptide compositions in human high density lipoproteins. Biochemistry. 10: 3436-3442.

15. Assmann, G., and H. B. Brewer. 1974. Lipid-protein interactions in high density lipoproteins. Proc. Natl. Acad. Sci. U. S. A. 71: 989-993.

16. Eisenberg, S., H. G. Windmueller, and R. I. Levy. 1973. Metabolic fate of rat and human lipoprotein apoproteins in the rat. J. Lipid Res. 14: 446-458.

17. Havel, R. J., H. A. Eder, and J. H. Bragdon. 1955. The distribution and chemical composition of ultracentrifugally separated lipoproteins in human serum. J. Clin. Invest. 34: 1345-1353.

18. Rider, A. K., R. I. Levy, and D. S. Fredrickson. 1970. "Sinking" pre-beta lipoprotein and the Lp antigen. Circulation. 42: III-10.

19. Kostner, G. M., J. R. Patsch, S. Sailer, H. Braunsteiner, and A. Holasek. 1974. Polypeptide distribution of the main lipoprotein density classes separated from human plasma by rate zonal ultracentrifugation. Eur.J. Biochem. 15: $611-621$.

20. Scanu, A. M. 1972. Structural studies of serum lipoproteins. Biochim. Biophys. Acta. 265: 471-508.

21. McFarlane, A. S. 1958. Efficient trace-labeling of proteins with iodine. Nature (Lond.). 182: 53.

22. Langer, T., W. Strober, and R. I. Levy. 1972. The metabolism of low density lipoprotein in familial type II hyperlipoproteinemia. J. Clin. Invest. 51: 1528-1536.

23. Folch, J., M. Lees, and G. H. Stanley. 1957. A simple method for the isolation and purification of total lipids from animal tissues. J. Biol. Chem. 226: 497-509.

24. Eisenberg, S., O. Stein, and Y. Stein. 1975. Radioiodinated lipoproteins: absorption of ${ }^{125}$ I radioactivity by high density solutions. J. Lipid Res. 16: 468-469.

25. Weber, K., and M. Osborn. 1969. The reliability of molecular weight determination by dodecyl sulfate polyacrylamide gel electrophoresis. J. Biol. Chem. 244: 4406-4412.

26. Lowry, O. H., N. J. Rosebrough, A. L. Farr, and R. J. Randall. 1951. Protein measurement with the Folin phenol reagent. J. Biol. Chem. 193: 265-275.

27. Bartlett, G. R. 1959. Phosphorus assay in column chromatography. J. Biol. Chem. 234: 466-468.

28. Chiamori, N., and R. J. Henry. 1959. Study of the ferric chloride method for determination of total cholesterol and cholesterol esters. Am. J. Clin. Pathol. 31: 305-309.

29. Burstein, M., and J. Samaille. 1960. Sur un dosage rapide du cholesterol lié $\alpha$ - et aux $\beta$-lipoproteinémes du sérum. Clin. Chim. Acta. 5: 609.

30. Kessler, G., and H. Lederer. 1966. Fluorimetric measurement of triglycerides. Automat. Anal. Chem. Technicon Symp. 341-344.

31. Technicon Instruments. Total cholesterol procedure: N-24b. 1964. In AutoAnalyzer Manual. Chauncy, New York. 345. 
32. Friedewald, W. T., R. I. Levy, and D. S. Fredrickson. 1972. Estimation of plasma low density lipoprotein concentration without use of the preparative ultracentrifuge. Clin. Chem. 18: 499-502.

33. Anker, H. S. 1970. A solubilizable acrylamide gel for electrophoresis. FEBS (Fed. Eur. Biochem. Soc.) Lett. 7: 293.

34. Ewing, A. M., N. K. Freeman, and F. T. Lindgren. 1965. The analysis of human serum lipoprotein distributions. Adv. Lipid Res. 3: 24-61.

35. Berman, M., and M. F. Weiss. 1962. The routine fitting of kinetic data to mathematical models: a mathematical formalism for digital computers. Biophys. J. 2: 275-287.

36. Berman, M., and M. F. Weiss. 1967. SAAM Manual. U. S. Public Health Service Publication no. 1703. U. S. Government Printing Office, Washington, D. C.

37. Schaefer, E. J., C. B. Blum, R. I. Levy, R. Goebel, H. B. Brewer, and M. Berman. 1976. High density lipoprotein metabolism in Tangier disease. Circulation. 54: II-27.

38. Berman, M., E. Hoff, M. Barandes, D. V. Becker, M. Sonenberg, R. Benua, and D. A. Koutras. 1968. Iodine kinetics in man-a model. J. Clin. Endocrinol. Metab. 28: 1-14.

39. Gitlin, D., D. G. Cornwell, D. Nakasato, L. Oncley, W. L. Hughes, and C. Janeway. 1958. Studies on the metabolism of plasma proteins in the nephrotic syndrome. II. The lipoproteins. J. Clin. Invest. 37: 172-184.

40. Scanu, A., and W. L. Hughes. 1962. Further characterization of the human serum $d 1.063-1.21, \alpha_{1}$-lipoproteins. J. Clin. Invest. 41: 1681-1689.

41. Furman, R. H., S. S. Sanbar, P. Alaupovic, R. H. Bradford, and R. P. Howard. 1964. Studies on the metabolism of radioiodinated human serum alpha lipoprotein in normal and hyperlipidemic subjects. J. Lab. Clin. Med. 63: 193-204.

42. Stoffel, W., O. Zierenberg, B. Tunggal, and E. Schreiber. 1974. ${ }^{13} \mathrm{C}$-nuclear magnetic resonance spectroscopic evidence for hydrophobic lipid-protein interactions in human high density lipoproteins. Proc. Natl. Acad. Sci. U. S. A. 71: 3696-3700.

43. Verdery, R. B., III, and A. V. Nichols. 1975. Arrangement of lipid and protein in human serum high density lipoproteins: a proposed model. Chem. Phys. Lipids. 14: 123-134.

44. Segrest, J. P., R. L. Jackson, J. D. Morrisett, and A. M. Gotto, Jr. 1974. A molecular theory of lipid-protein inter- actions in the lipoproteins. FEBS (Fed. Eur. Biochem. Soc.) Lett. 38: 247-253.

45. Laggner, P., K. Müller, O. Krathy, G. Kostner, and A. Holasek. 1973. Studies of the structure of lipoprotein A of human high density lipoprotein $\mathrm{HDL}_{3}$ : the spherically averaged electron density distribution. FEBS (Fed. Eur. Biochem. Soc.) Lett. 33: 77-80.

46. Assmann, G., and H. B. Brewer. 1974. A molecular model of high density lipoproteins. Proc. Natl. Acad. Sci. U. S. A. 71: 1534-1538.

47. Bradley, R. A. 1975. The location of protein in serum lipoproteins: a fluorescence quenching study. Biochim. Biophys. Acta. 379: 517-528.

48. Oncley, J. L., and N. R. Harvie. 1969. Lipoproteins-a current perspective of methods and concepts. Proc. Natl. Acad. Sci. U. S. A. 64: 1107-1118.

49. Kostner, G., and P. Alaupovic. 1972. Studies of the composition and structure of plasma lipoproteins: separation and quantification of lipoprotein families occurring in high density lipoproteins of human plasma. Biochemistry. 11: 3419-3428.

50. Borut, T. C., and F. Aladjem. 1971. Immunochemical heterogeneity of serum high density lipoproteins. Immunochemistry. 8: 851-863.

51. Friedberg, S. J., and J. A. Reynolds. 1976. The molar ratio of the two major polypeptide components of human high density lipoprotein. J. Biol. Chem. 251: 4005-4009.

52. Fallon, H., and E. L. Kemp. 1968. Effects of diet on hepatic triglyceride synthesis. J. Clin. Invest. 47: 712-719.

53. Waterhouse, C., J. H. Kemperman, and J. M. Storemount. 1964. Alterations in triglyceride metabolism produced by dietary change. J. Lab. Clin. Med. 63: 605-620.

54. Quarfordt, S. H., A. Frank, D. M. Shames, M. Berman, and D. Steinberg. 1970. Very low density lipoprotein triglyceride transport in type IV hyperlipoproteinemia and the effects of carbohydrate-rich diets. J. Clin. Invest. 49: 2281-2297.

55. Magide, A. A., D. Reichl, and N. B. Myant. 1973. The effect of nicotinic acid on the synthesis of plasma lipoproteins in monkeys. Clin. Sci. (Oxf.). 44: $20 \mathrm{P}$.

56. Fredrickson, D. S., and R. I. Levy. 1972. Familial hyperlipoproteinemia. In The Metabolic Basis of Inherited Disease. J. B. Stanbury, J. B. Wyngaarden, and D. S. Fredrickson, editors. McGraw-Hill Book Company, New York. 3rd edition. 545-641. 